Review

\title{
Genetic Gains in Wheat Breeding and Its Role in Feeding the World
}

\author{
Wuletaw Tadesse 1,*, Miguel Sanchez-Garcia ${ }^{1}$, Solomon Gizaw Assefa ${ }^{1}$, \\ Ahmed Amri ${ }^{1}$, Zewdie Bishaw ${ }^{1}$, Francis C. Ogbonnaya ${ }^{2}$, Michael Baum ${ }^{1}$ \\ 1 International Center for Agricultural Research in the Dry Areas (ICARDA), \\ Rabat P. O. Box 6299, Morocco \\ 2 Grains Research and Development Corporation (GRDC), Barton ACT 2600, \\ Australia \\ * Correspondence: Wuletaw Tadesse, Email: w.tadesse@cgiar.org.
}

\section{ABSTRACT}

Wheat is the leading global food crop providing $19 \%$ of the daily calories and $21 \%$ of protein requirements for humans. The wheat production has increased from 220 million tons in 1961 to 750 million tons in 2018 with total production area of 220 million hectares which showed insignificant changes across years. The development of high yielding and widely adapted semi-dwarf input responsive wheat varieties, application of fertilizer, pesticides, irrigation, mechanization and implementation of favorable policies have contributed to such significant jump in wheat production at global level. The average annual genetic gain of wheat has been reported to be $1 \%$ while the demand for wheat increases by $1.7 \%$ annually reaching a total of 1 billion tons in 2050. To this end, conventional and molecular breeding strategies and approaches such as inter-country shuttle breeding, doubled haploid breeding, speed breeding, marker assisted selection, genomic selection, key location phenotyping and hybrid wheat breeding should be utilized intensively. The international wheat breeding programs at CIMMYT and ICARDA have developed and distributed germplasm to the world in the past 4 or more decades during which hundreds of high yielding and widely adapted wheat varieties with resistance tolerance to the major prevailing abiotic and biotic stresses have been released and adopted. Breeding progress or genetic gains in

\section{G Open Access}

Received: 10 June 2019

Accepted: 08 July 2019

Published: 15 July 2019

Copyright (c) 2019 by the author(s). Licensee Hapres, London, United Kingdom. This is wheat has been determined by different authors with average relative gains reaching up to $2.5 \%$ per year. This paper reviews the global challenges facing demand and supply of wheat, the strategies to increase breeding efficiency and genetic gains, the impacts of the international wheat breeding and its progress, and future strategies to increase wheat production while conserving the natural resource base.

KEYWORDS: genetic gain; improvement; production; wheat under the terms and conditions of Creative Commons Attribution 4.0 International License. 


\section{INTRODUCTION}

Wheat (Triticum aestivum) is one of the most important food crops that contributed significantly for human civilization. It grows widely across different regions with altitude levels ranging from sea level to 4570 m.a.s.l. in Tibet [1]. Latitudinally, wheat grows $30^{\circ}$ and $60^{\circ} \mathrm{N}$ and $27^{\circ}$ and $40^{\circ} \mathrm{S}$ [2]. Such wide adaptation and cultivation of wheat across all continents led to the harvest of wheat in each months of the year at least in a given area in the world [3]. Based on ploidy levels (number of chromosome sets in a cell), cultivated wheats could be diploids $(2 n=2 x=$ 14 , AA), tetraploids $(2 n=4 x=28$, BBAA) and hexaploids $(2 n=6 x=42$, BBAADD)[4]. The chromosome sets in the tetraploids and hexaploid wheats are duplications of different genomes, and hence bread wheat and durum wheats are allopolyploids or to be exact allotetraploids and allohexaploids, respectively. Bread wheat covers more than $95 \%$ of the wheat production at global level. Wheat can be classified into vernal (winter) and non vernal (spring) types based on growth habits and requirement of cold for flowering. The vernal wheats (winter/facultative) accounts $35 \%$ while the spring wheat (non vernal) accounts $65 \%$ of the total bread wheat production [5,6].

Since ancient times, wheat has played an important role to feed the world. It provides $19 \%$ of calories and $21 \%$ of proteins [5]. Different food types such as French bread, chapati, biscuits, pasta, macaroni, injera, and porridges are prepared using wheat flour solely or in mixture with the flour of other cereals. Traditionally wheat culture is dominant in Centeral and West Asia and North Africa (CWANA), Europe, America and Australia. Because of increase in urbanization and the change in food habits, the demand for wheat is rising every year across the different regions including Eastern and Southern Africa (5.8\%), West and Central Africa (4.7\%) and South Asia and Pacific (4.3\%). Central Asia (5.6\%), Australia (2.2\%) and North Africa (2.2\%)[7]. Almost all the countries in the CWANA and SSA regions are net wheat importers. Egypt is the world's largest wheat importer (9 million tons/year) followed by Algeria (4 million tons/year). Sub Saharan African countries import 17 billion worse wheat annually (8). The annual trade value of wheat in 2016 was about 36 billion dollar for a total volume of 184 million tons of wheat in transaction [7].

Wheat production at global level has increased significantly over the years (Figure 1). According to FAO [8], about 749.5 million tons of wheat were produced on 220 million ha in 2016 with an average grain yield of 3.4 tha $^{-1}$, a highly significant increase from 1961, which stood at 222 million tons with a productivity level of only $1.2 \mathrm{t} \cdot \mathrm{ha}^{-1}$ (Figure 1). The accelerated increase in wheat production is attributed to the adoption of improved technology packages, in particular the adoption of high yielding and disease resistant varieties with better response to inputs (e.g., fertilizers, water), improved irrigation systems, machineries and pesticides as well as better management practices, coupled with conducive policies and strong institutions [9]. 


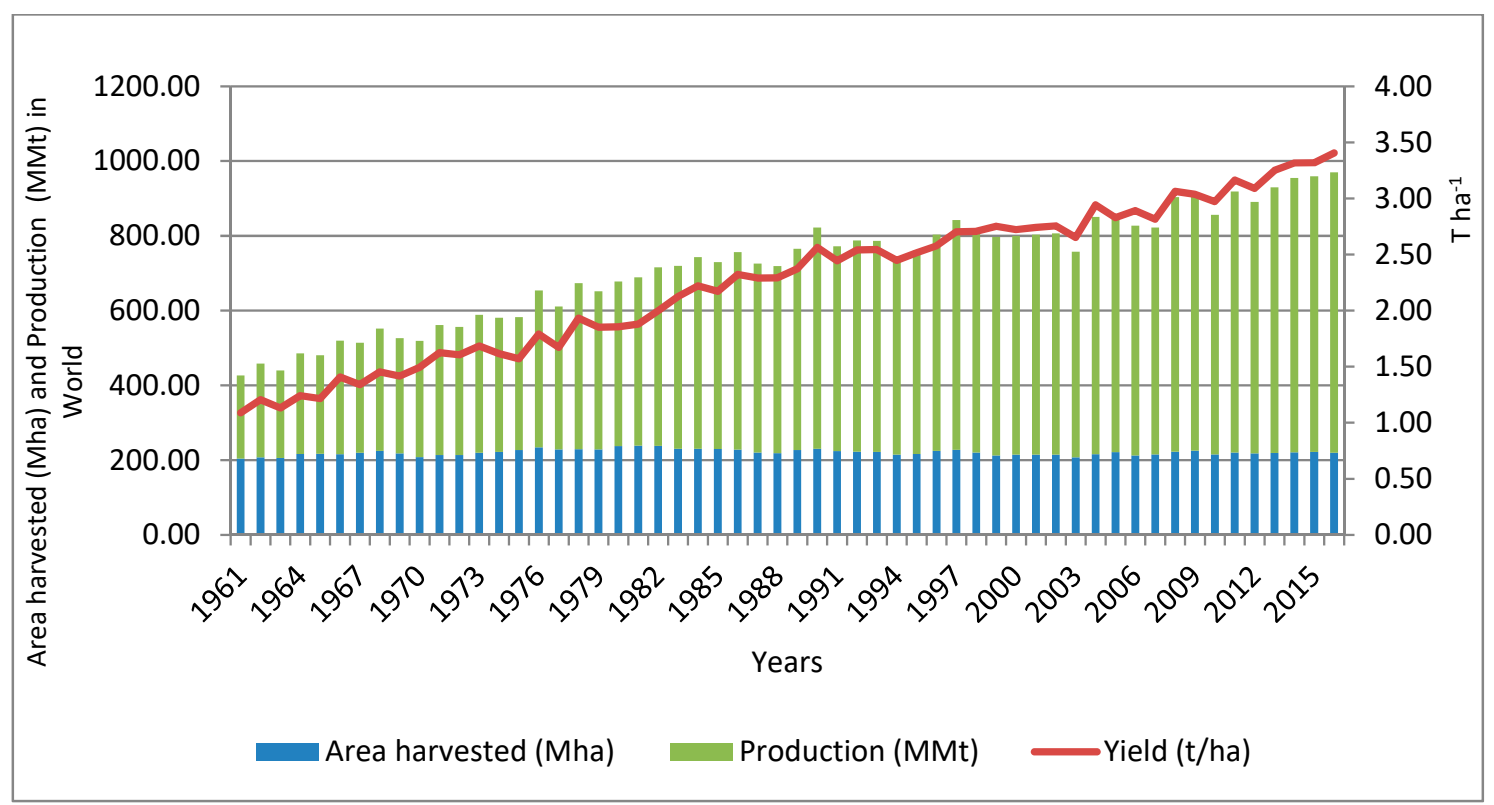

Figure 1. World wheat yield, production and area from 1961 to 2016 (FAO, 2018).

Though there has been increments in wheat productivity across the years, there is still a big gap between the demand and annual genetic gains in wheat. The average annual genetic gain of wheat has been reported to be $1 \%$ [10] while the demand for wheat increases by $1.7 \%$ annually reaching a total of 1 billion tons in 2050 [11].

\section{WHEAT GENETIC RESOURCES EVOLUTION AND THEIR ROLE IN BREEDING}

The evolution of primitive wheats and cultivated bread and durum wheats depended mainly on hybridization between species (polyploidization) and on the accumulation of mutations. Durum wheat (allotetraploid, $2 n=4 x=28, \mathrm{BBAA}$ ) and bread wheat (allohexaploid, $2 n=6 x=42$, BBAADD) are the two important cultivated wheat groups contributing 5 and $95 \%$ to the current wheat production at global level. Triticum turgidum var durum ( $2 n=4 x=28$, BBAA ) evolved 8500 years ago from the cultivated emmer wheat, Triticum dicoccum $\left(2 n=2 x=28, \mathrm{BBA}^{\mathrm{u}} \mathrm{A}^{\mathrm{u}}\right)$ which was domesticated 10,000 years ago from the wild emmer, Triticum dicoccoides $(2 n=2 x=28$, $\mathrm{BBA}^{\mathrm{u}} \mathrm{A}^{\mathrm{u}}$ ), an allo-tetraploid arose by amphiploidy between Triticum urartu $\left(2 n=2 x=14, \mathrm{~A}^{\mathrm{u}} \mathrm{A}^{\mathrm{u}}\right)$ and the $\mathrm{B}$ genome ancestor, most probably Aegilops speltoides $(2 n=2 x=14$, SS)[12] as indicated in Figure 2. Common wheat, Triticum aestivum ( $2 n=6 x=42$, BBAADD), has evolved from a hybrid between the tetraploid wheat species T. turgidum $(2 n=4 x=28$, BBAA) and the diploid progenitor Aegilops tauchii var. strangulata $(2 n=2 x=14$, DD) $[13,14]$. According to genome analyses, T. monococcum and T. turgidum share the A genome while T. turgidum and T. aestivum share the A and B genomes. Molecular evidence confirmed that T. urartu is the A genome donor of both tetraploid and hexaploid wheats [15]. Allopolyploid wheats behave like diploids during meiosis and chromosome pairing occurs only 
between homologous chromosomes due to the suppressor Ph1 and Ph2 genes [16,17]. The two hexaploid wheats (T. aestivum and T. zhukovsky) arose through natural hybridization of cultivated tetraploid wheats with the wild diploid grasses [14]. Common wheat (T. aestivum) is currently the dominant wheat all over the world while T. zhukovsky is of limited economic importance.

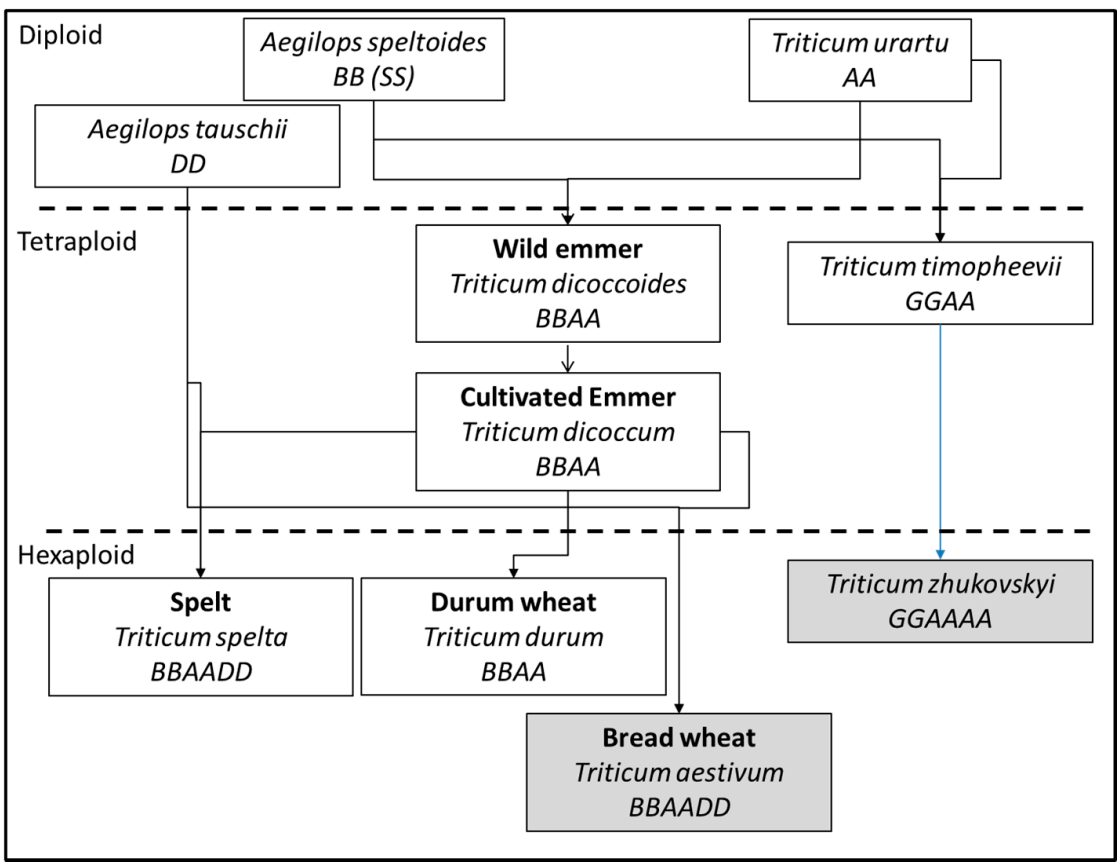

Figure 2. Evolutionary relationship of wheat and its ancestors. In grey the species that only exist as cultivated form.

Genetic resources have been grouped into primary, secondary and tertiary gene pools based on their genomic constitution, evolutionary distance from each other and inter-cross ability. The primary gene pool consists of wheat landraces, early domesticates and wild species and they are directly crossable to bread and durum wheats $[18,19]$. The secondary gene pool is composed of polyploid Triticum and Aegilops species which share at least one homologous genome with the cultivated types [19]. This gene pool includes, for instance, T. timopheevii (AAGG) and the diploid S-genome (similar to the B genome) species from Aegilops [18]. Gene introgression of this group into cultivated wheat is difficult and often embryo rescue is required to obtain $F_{1}$ hybrids [20]. The tertiary gene pool is composed of mostly perennial diploids and polyploids, and has no common genome constitutions of the cultivated species, including species belonging to other genera such as Amblyopyrum, Secale, Dasypyrum, Thinopyrum, Agropyron, Eremopyrum, Elymus, Elytrigia, Hordeum and Leymus. Gene transfer is highly complex and requires special techniques such as irradiation or gametocidal chromosomes and embryo rescue to enhance translocations [21]. Germplasm collection has been carried out across different countries with the principal objective of identifying noble 
traits for resistance to biotic and abiotic stresses for breeding and breeding purposes. However, of all the germplasm collections stored in gene banks, only $10 \%$ of the materials have been utilized by breeders [22]. There are different reasons associated with this low level utilization of gene bank materials. The most important reasons include: materials in the gene bank are clumsy and obsolete, difficult to cross, time consuming to transfer genes of interest and poorly defined and characterized. Furthermore, breeders argue that they have diversity of traits in the elite lines of their breeding programs. However, the value of genetic resources should be assessed not only by the actual use rate but for their capacity to provide continuously sources of novel diversity for most of breeders sought traits and these are expected to be even more important for improving complex traits and climate change adaptive traits. The existing literature shows that wheat was among few crops for which genes are transferred efficiently from their wild relatives $[23,24]$. The role of conserved wild relatives of wheat and landraces is expected to increase with new development of tools allowing efficient introgression and pyramiding of genes and efficient selection and follow up of genes targeted by the crosses including use of genotyping and sequencing information.

The use of wheat genetic resources can be further enhanced by better targeting the traits in the existing collections through applying best sub-setting approaches alternative to random sampling or core collections. In this regards, the Focused Identification Germplasm Strategy is developed to select best bet subsets for specific traits sought by breeding programs. FIGS approach mimics natural selection and used either filtering of algorithms describing the relationships between environmental conditions and the sought trait $[25,26]$. The relevance of this approach has allowed the identification of novel diversity for insect resistance and disease resistance in wheat [27-29]. Nevertheless, genetic resources have played significant role in wheat breeding in the following major areas.

\section{Increasing Yield Potential}

The first scientific breeders started in the 19th century selecting and crossing landraces and cultivars from different origins and genetic pools to obtain the combinations that led to superior varieties. The Italian breeder, Nazareno Strampelli, used the Japanese variety Akakomugi in his crossing block and made crosses with Italian landraces and breeding lines in the first decades of the 20th century [30]. Such crosses resulted in the most successful varieties such as Ardito and Mentana possessing Ppd-D1 alleles for photoperiod insensitivity and Rht8c for short straw. These varieties later became the backbone of most of the new varieties developed in the Mediterranean countries, USSR, China and some South American countries [31-33].

The Nobel laureate Norman E. Borlaug in the 1950s has made the Norin-10/Brevor cross that introduced the Rht-B1 and Rht-D1 dwarfing 
alleles which led to the development and release of input responsive semi-dwarf varieties of the "Green Revolution" [34]. Originally these dwarfing genes of Norin-10 were obtained from the Japanese landrace "Shiro Daruma" [35]. Though these dwarfing genes have contributed significantly to increase yield, nutrient use efficiency and input responsiveness, it should be noted that their introgression was time consuming and very difficult [36]. At CIMMYT and ICARDA, spring $\times$ winter wheat crosses and elite lines $\times$ synthetic wheats are used intensively to develop high yielding wheat genotypes with broad adaptation and resistance to the major biotic and abiotic stresses in the face of climate change.

\section{Drought, Heat and Salinity Tolerance}

Wheat landraces have been exploited for tolerance to many abiotic and resistance to major biotic stress and are the sources of many important genes including those associated with drought tolerance [37]. It has been reported that modern wheat lines with wild relatives or synthetic derived wheat (SDW) in their background have better performance across different environments for different stresses such as heat, drought and salinity. Synthetic hexaploid wheats (SHW) and SDW of CIMMYT have shown superior performance for grain yield under heat and drought conditions [38]. Similarly, better water use efficiency, drought tolerance and high root biomass was reported from translocation lines carrying 7DL/7A from Agropyron elongatum [39]. Wheat varieties derived from synthetic wheats have shown 11-30\% higher grain yield under rainfed conditions in northern and southern Australia indicating the importance of the synthetic wheats for drought tolerance. [40,41]. Multi-location data analysis of the semi-Arid wheat yield trials of CIMMYT by Lage and Trethowan [42] also indicated that the synthetic derived wheat genotype "Vorobey" was the top yielding across most of the global testing locations. Synthetic derived wheats have been also reported to have resistance/tolerance to salinity and to boron toxicity $[40,43]$ indicating the importance of wild relatives in improving common wheat. Wheat wild relatives are believed to hold more novel genes for adaptation to drought, cold, frost, heat, salinity, acidity stresses, most of which will be amplified with the climate change.

\section{Resistance to Diseases and Insects}

Genetic resources have contributed significantly to the identification of important genes and thereby enabled to decreasing losses in yield and quality due to major diseases and insects. Because of the co-evolution of the host and the pathogen, resistance sources are mostly obtained from the centres of origin either from the wild relatives or landraces [44-46]. A very good example of the contribution of landraces to disease resistance is the $\mathrm{Sr} 2$ gene [46] for stem rust resistance. It is originated from the emmer wheat cultivar "Yaroslav" and Dr. McFadden has successfully 
incorporated it into bread wheat through conventional hybridization in 1923 [47]. For almost more than 100 years, the Sr2 gene deployed in combination with other minor and major stem rust genes, is contributing significantly in controlling stem rust of wheat across many countries, until recently when its effectiveness was overcome by the new races identified since 1999 including UG99. Other successful resistance genes for stem rust are Sr24 from Thinopyrum ponticum (1RS.1AL), Sr38 from Triticum ventricosa and Sr36 from Triticum timopheevi. Most of the stem rust resistance genes have been broken by UG99 and its derivatives. Some of the genes which are still effective Sr22, Sr25, Sr26, Sr39, Sr42, Sr45 [45,48]. Similarly, the synthetic derived wheats shave contributed resistance sources to many other diseases (yellow rust, leaf rust, septoria, tan spot, and nematodes) and insects (Hessian fly, Russian wheat aphid, Sun pest [20,49-51].

\section{Improving Grain Quality}

Although quality has not been a breeding driving force in many countries in the World, the increased number of countries that apply price premiums for high quality wheat is changing that trend. In fact, in countries like the United States farmers can get up to 10\% more revenues on their wheat by just increasing protein content by $1.5 \%$ [52]. These premiums increase in unfavorable years, like 2011 in Canada, when wheat quality premiums rose up to $25 \%$ for a $2 \%$ increase in protein [53]. Genetic resources such as landraces, wild relatives, and synthetic wheats have been reported to contribute to improving wheat grain quality [20]. Besides modern improved wheat lines, landraces are considered the preferred source of alleles for wheat breeding due to their genetic diversity and their proximity to modern cultivated wheat as compared to other sources such as synthetics. Landrace large diversity make them source of bread-making related alleles such as alternative prolamine alleles or bread-making related alleles such as wbm [54-56]. Additionally, landraces can also be sources of biofortification for wheat as proven by the high levels of micronutrients found in a collection of Sicilian landraces [57].

However, hexaploid wheat is a result of a very limited number of original hybridization events between the wheat genome donors. Therefore the original genetic diversity of ancient hexaploidy wheat and therefore of modern wheat is limited. The main solution for this genetic bottleneck is the recreation of the original hybridization events with new donors of the $\mathrm{A}, \mathrm{B}$ and $\mathrm{D}$ genomes to increase wheat diversity, also regarding quality. Synthetic wheats which are developed through crossing of emmer wheat with Aegilops tauschii followed by chromosome doubling have showed semi-hard to hard grain texture and tremendous variations for protein content, SDS-S values, kernel weight and plumpness [20]. Lage et al. [58] have reported that synthetic hexaploids have on average 15.5\% protein as compared to the common bread wheat cultivars such as "Seri M82" with average protein value of $13.1 \%$. Similarly, the synthetic wheats 
have longer grains, and higher SDS values. Protein content among synthetics showed significantly negative correlations with grain weight and plumpness, but no correlation with SDS values. Despite these negative correlations, Lage et al. [58] have identified 10 superior synthetic hexaploid wheats originated from 9 different emmer parents with high values of protein content, SDS, plumpness and kernel weight indicating that genetic variation for quality traits from tetraploid emmer wheat can be easily transferred into hexaploid common wheat. Spring bread wheat genotypes with synthetic wheats in their background have been reported with higher levels of $\mathrm{Zn}$ and Fe content [59]. Rapid deployment of such wheat varieties would help to improve nutritional security in most of the developing countries.

\section{INTERNATIONAL WHEAT BREEDING AND ITS IMPACT}

Wheat production has been constrained by abiotic (drought, cold, heat, salinity) and biotic stresses (yellow rust, leaf rust, stem rust, Septoria, root rots, Russian Wheat Aphid, Barley Yellow Dwarf Virus, Sun pest, and Hessian Fly) at global, regional and national levels. Increasing human population, land degradation, water scarcity, and climate change and associated effects are increasing through years challenging wheat production at a larger scale. The International wheat breeding programs at CIMMYT and ICARDA have been established principally to develop widely adapted and high yielding wheat varieties with resistance to the above major abiotic and biotic stresses with acceptable end use qualities and to distribute globally based on request. Furthermore, training and capacity development of the national programs is also an important task of these breeding programs. Since its establishment 50 years ago, the International Wheat Improvement Net Work (IWIN) led by CIMMYT and ICARDA in partnership with the National Agricultural Research Systems have contributed significantly to the development and distribution of improved wheat germplasm globally. The impact was huge especially in the developing countries. The direct release of semi-dwarf input responsive wheat varieties of CIMMYT origin by the national programs in Mexico, India, Pakistan and Turkey resulted in the green revolution and helped to ensure food security $[10,60,61]$.

\section{Breeding Methods and Approaches to Increase Genetic Gains}

In the face of climate change with continued water shortage both in irrigated and rained environments, it is important to develop high yielding wheat genotypes with high water use efficiency which combines both high yield potential and resistance to drought and heat stresses along with resistance to the major biotic stresses. To this end, it is important to formulate and deploy efficient breeding methods and strategies that enables to increase genetic gain while utilizing the available resources efficiently. The first and most important thing is to define the target regions (mega-environments) and identify the corresponding production 
constraints. This is followed by assembling crossing blocks targeting the major mega environments. At ICARDA, we use shuttle breeding, doubled haploids, marker assisted selection, key location phenotyping, hot spot screening, international nurseries distribution and partnership with the NARS [48,62-68].

\section{Shuttle breeding}

Shuttle breeding is growing of two or more generations in contrasting environments to advance the generations and shorten the breeding cycle. It was originally used at the International Maize and Wheat Improvement Center (CIMMYT) by Norman E. Borlaug [69] using the Toluca station (a summer season location located at $27.5^{\circ} \mathrm{N}, 40$ m.a.s.l. with $800-1000 \mathrm{~mm}$ average rain fall) in the state of Mexico and Obregon station a winter season irrigated dry location at $27.5^{\circ} \mathrm{N}, 40$ m.a.s.l. in the state of Sonora, in Mexico. These two stations are very different in terms of latitude, altitude and rainfall, and has proven to be effective for the introduction of photoperiod insensitive genes in spring bread wheat. The photoperiod insensitive genes (Ppd1 and Ppd2) along with the dwarfing genes (Rht1 and $R h t 2)$ have enabled to the development of high yielding, widely adapted, lodging resistant and input responsive spring bread wheat varieties $[69,70]$. The CIMMYT wheat breeding program has established the Njoro station in kenya as additional shuttle breeding location since 2008 in order to screen germplasm for stem rust resistance (Ug99 and its variants)[48].

Similarly, the spring bread wheat breeding program at ICARDA uses a shuttle breeding program for the winter $\times$ spring crosses involving Terbol station $\left(34^{\circ} \mathrm{N} ; 36^{\circ} \mathrm{E}, 900\right.$ m.a.s.l) in Lebanon (winter $\times$ spring crosses during the winter season, $F_{1}$ during the summer season), evaluation of $F_{2}$ populations at Sids station ( $29^{\circ} \mathrm{N}$; $31^{\circ} \mathrm{E}, 32.2$ m.a.s.l.) in Egypt during the winter season, Evaluation of $\mathrm{F}_{3}$ at Kulumsa $\left(08^{\circ} \mathrm{N}\right.$; $39^{\circ} \mathrm{E}, 2220$ m.a.s.l) in Ethiopia during the summer season and $\mathrm{F}_{4}$ populations at Merchouch station (33.6 $6^{\circ}$; $6.7^{\circ} \mathrm{W}, 430$ m.a.s.l) in Morocco during the winter cycle [66]. In addition to the cycle shortening, shuttle breeding enables additional recombination events, selection of transgressive segregants and selection for resistance against biotic and abiotic stresses with broad adaptation. Such summer and winter season shuttle breeding is dominantly possible in spring bread wheat though there were efforts to undertake shuttle breeding for winter wheat between the summer station of CIMMYT at Toluca, Mexico and Oregon state university, USA [62]. Winter wheat normally requires vernalization and hence it is grown during the winter cycle, and hence it is possible dominantly one generation per year advancement under field condition.

\section{Doubled haploid breeding}

A doubled haploid is a genotype formed from haploid (n) cells through random chromosome doubling or artificially induced chromosome doubling methods such as colchicine. In vitro haploid production using 
anther culture, microspore culture or embryo culture using wheat $\times$ maize crosses followed by chromosome doubling greatly enhances the production of homozygous wheat lines in a single generation and increases the precision and efficiency of the selection process in wheat breeding. It also enables detection of linkage and gene interactions, estimating of genetic variance and the number of genes for quantitative traits. Doubled haploids enables detection and identification of translocations, substitutions, and chromosome addition lines, and facilitates genetic transformation and mutation studies [71].

In the last few decades several varieties issued from $\mathrm{DH}$ breeding strategies have been released in many countries such as China, France, Hungary, Romania, and Canada [72-75]. Besides variety development, wheat DH populations have also been used for in the creation of molecular marker maps and identifying quantitative trait loci and to unveil their mechanisms of action [76,77]. New wheat QTL for end-use quality-related traits [78], agronomic performance [79] and disease resistance [80,81], have been identified using DH populations. In studies comparing genotypes issued from DH, SSD, and pedigree methods, no significant differences in grain yield were found among any populations when the parental varieties were closely related in their pedigrees $[82,83]$.

The use of doubled haploids in breeding has two main advantages. On one hand, DH allows shortening the cycle in wheat by 16 to $50 \%$ depending on the growth habit (spring or winter) and the generation from which the $\mathrm{DH}$ are produced $\left(\mathrm{F}_{1}, \mathrm{~F}_{2}, \mathrm{BC}_{1} \mathrm{~F}_{1}\right.$, etc.). As indicated in Figure 3 , in a normal breeding strategy, only after at least 6 generations the level of homozygosity is large enough to undertake genotype screening and preliminary yield trials. In winter wheat, generally only one generation per year can be achieved under field conditions, therefore the use of doubled haploids can reduce from 8 to 4 years the time required to attain preliminary yield trial when the doubled haploids are produced from $F_{1}$ plants. In spring wheat, the advantage of DH over normal breeding is residual due to the possibility of growing two generation per year [84]. On the other hand, DH plants are fully homozygous which increases the efficiency of selection for both qualitative and quantitative traits since recessive alleles are fixed in one generation and directly expressed. In some cases, such as mutation breeding, the advantage is even larger, especially for quantitative traits [74,77].

Strategies aiming to increase selection accuracy in DH breeding have been successfully used around the world. Generally, the increases in accuracy are obtained at the expense of the cycle length by delaying the generation from which the $\mathrm{DH}$ are produced. Backcross-DH strategy has been one of the successful examples. Thus, in Iran, yellow rust resistance was successfully and efficiently transferred to the adapted receptor cultivar "Ghods" by producing $\mathrm{DH}$ from tested $\mathrm{BC}_{2} \mathrm{~F}_{2}$ plants [85]. The $\mathrm{DH}$ plants produced showed similar yield and phenology as the adapted parent but were resistant to two isolates of yellow rust and were produced 
in a shorter period of time. However, if the number of traits to introgress, their heritability or the amount of sample required to evaluate them (i.e., quality tests) can severely reduce the efficiency of this method.

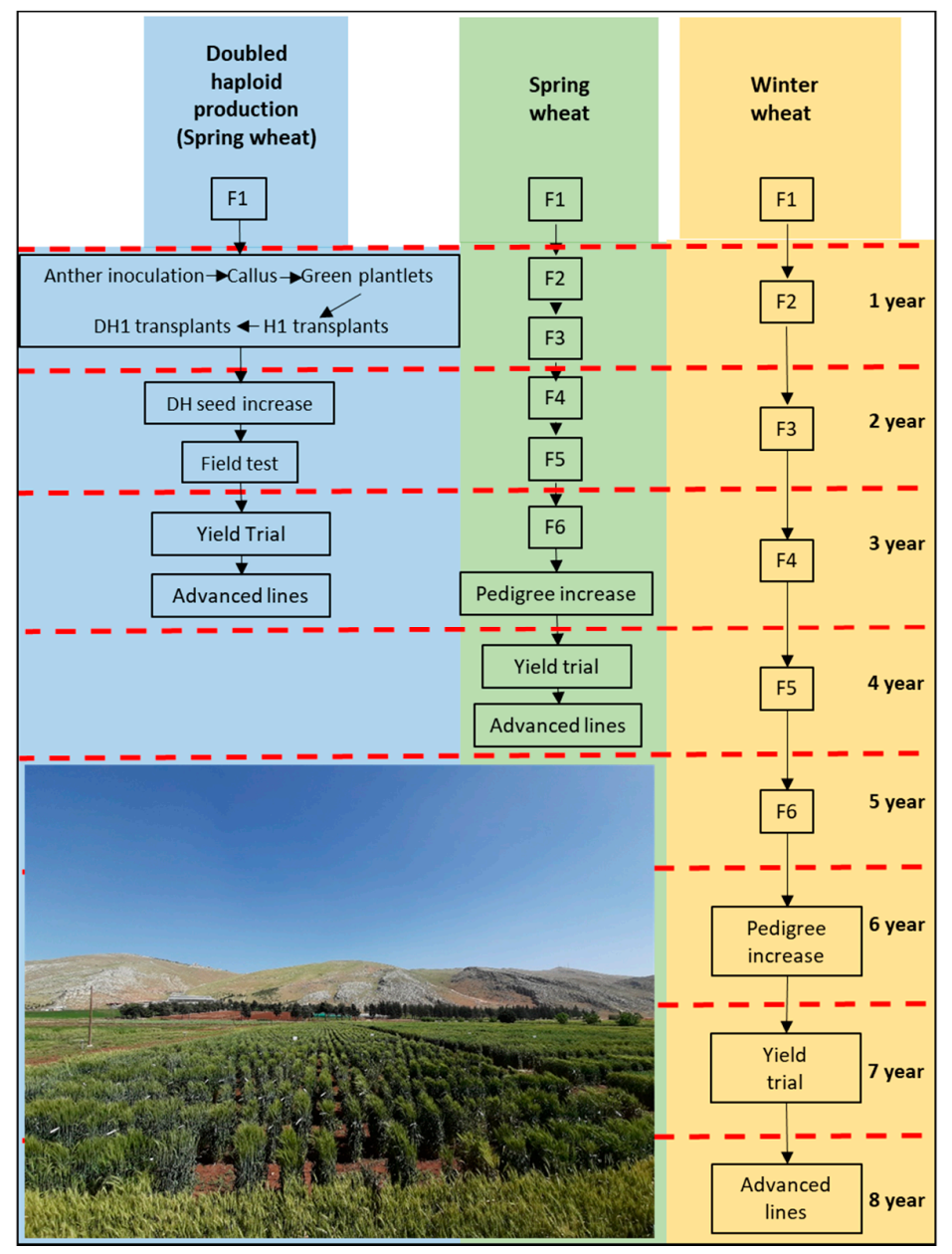

Figure 3. Comparison of conventional (winter and spring) and anther culture breeding methods: conventional methods take 4 to 8 years for production of advanced lines, whereas anther culture takes only 3 years from $\mathrm{F}_{1}$. Adapted from Li et al. [84].

However, the largest disadvantage of $\mathrm{DH}$ production for breeding is the loss of selection accuracy that comes from the fact that no selection can be applied until the DH plant is produced as compared to normal schemes where pedigree or modified pedigree selection can be applied in segregating populations. Additionally, in $\mathrm{F}_{1}$-derived $\mathrm{DH}$ strategies, only one event of recombination occurs, limiting the chances of combining the best alleles from the parents in the next generation [86].

\section{Marker assisted selection}

Diagnostic markers are used in the wheat breeding program:

(1) to characterize parents for the most important diseases and pests (yellow rust, leaf rust, stem rust, nematodes, Hessian fly and Russian 
Wheat Aphid), phenological traits such as photoperiod (Ppd) and vernalization (Vrn) requirements; plant height (Rht), grain hardness and other genes [50].

(2) to undertake selection in segregating generations for disease and pest resistance in the absence of the disease in which case agronomically superior $F_{2}$ plants will be selected, and leaf samples from the flag leaf are collected for DNA extraction and electrophoresis using the diagnostic markers of interest. Among the selected plants, only those which are marker positive for the targeted diseases are harvested and promoted to the next generation.

(3) to undertake gene pyramiding: Gene enrichment is an important activity to develop durable resistance using major genes since the probability of mutation to occur at 2 or 3 loci at a time is rare than the probability it happens in a single locus. Using field phenotyping, it is hard to tell whether the resistance is due to one, two or more genes. However, it is easy to tell using molecular markers and hence to undertake gene enrichment whenever necessary. To this end, leaf samples at early stage of $\mathrm{BC}_{1} \mathrm{~F}_{1}$ or $\mathrm{F}_{2}$ plants are collected and analysed for the genes they carry. Each of the plants should remain labelled. At flowering stage, based on the marker data, gene enrichment is carried out using the classical emasculation and pollination techniques of hybridization [87].

Molecular markers can also be used to increase the selection accuracy in DH breeding strategies. For instance, the IWWIP-ICARDA winter wheat breeding program uses marker assisted selection in $\mathrm{F}_{2}$ plants at seedling stage to identify the ones combining the most alleles of interest in homozygosity from a set of 96/192 functional and diversity markers. The plants identified are later on used to produce DH plants. This strategy, called marker assisted $\mathrm{F}_{2}$ derived $\mathrm{DH}\left(\mathrm{MAS}-\mathrm{F}_{2}-\mathrm{DH}\right)$ combines the benefits of cycle shortening from the DH strategy and the increased selection accuracy of MAS. In fact, MAS coupled with DH production can increase gene combination efficiency from 6 to 17.7 times when combining 2-8 markers respectively as compared to $\mathrm{F}_{4}$ derived lines obtained through conventional breeding $[71,88]$.

Marker assisted doubled haploid production can be also used in a backcross breeding strategy to introgress a trait of interest in an adapted high yielding cultivar increasing the efficiency while maintaining the short generation interval. MAS-assisted $\mathrm{DH}$ production from $\mathrm{BC}_{1} \mathrm{~F}_{1}$ were developed in Australia to introgress disease resistance and agronomic and end-use quality traits from a non-adapted cultivar (“Anuello") into a highyielding widely adapted variety (“Stylet”)[89].

\section{Modified speed breeding}

Speed breeding' technology is the production of up to six generations of wheat per year involving extended duration of light and early 
harvesting of wheat under glasshouse conditions. This enables effectively to shorten the breeding cycle through acceleration of generation advancement. However, it might be limited in its scope to screen the population for different biotic and abiotic stresses in addition to the difficulty of handling of large number of populations required at $F_{2}$ stage. At ICARDA, we have developed a modified speed breeding for elite $\times$ elite crosses where by crosses are made in the plastic houses during the winter cycle followed by production of $F_{1}$ in the glasshouse using speed breeding in spring followed by production of $F_{2}$ in summer under field condition using irrigation at Merchouch station where the population is selected based on selected bulk scheme for biotic and abiotic stresses. The $F_{3}$ population is grown during the winter cycle in the field at Merchouch (December-June) where individual spikes/plants are selected based on pedigree selection scheme and promoted to head-rows during the summer cycle. Preliminary yield trials are grown during the winter season across key locations using the selected head-rows. Selected lines are advanced into first year and second year Advanced Yield Trials (AYTs). The second year AYTs are also multiplied at the same time in large plots of six rows with $0.2 \mathrm{~m}$ spacing between them and $20 \mathrm{~m}$ length. Selected genotypes based on agronomic and grain quality data analysis are composed into the different international nurseries and yield trials and distributed globally based on request by the national programs. The top performing genotypes are also included in the crossing block making the whole breeding cycle complete in 4 years. Such a method is highly effective to increase genetic gain through shortening the breeding cycle and enabling selection and generation advancement under biotic and abiotic stresses prevailing during summer and winter seasons.

\section{Genomic selection (GS)}

GS is the utilization of genome-wide marker data to predict and select for better multi-genetic traits early in the breeding cycle in order to increase genetic gain by reducing the breeding cycle while increasing breeding efficiency and reducing costs. For the GS to be implemented in any breeding program, the following three populations are required.

1. The training population (TP): This is a diverse set of population which is phenotyped for different traits and genotyped across the entire genome. The phenotypic and genotypic data of the TP is used to train the model and used to predict the performance of other nonphenotyped but genotyped populations.

2. The breeding population (BP): This is the set of breeding lines which are not phenotyped but genotyped, and hence their performance is predicted using the model developed by using the training population. The model estimates the genomic estimated breeding value (GEBV) for each of the BP lines using their genotypic data by undertaking allelic identity test with the loci that were corelated with the phenotypic data 
of the training population. BP lines with intensive phenotypic and genotypic data could be utilized to effectively re-train and calibre the model. The important question from practical point of view is at which stage of the $\mathrm{BP}\left(\mathrm{F}_{2}-\mathrm{F}_{6}\right.$, or Preliminary yield trial or advanced yield trials stage) should we apply GS for maximum genetic gain and resource use efficiency? It is possible to apply at any stage and promote only those selected BP with the highest GEBV. The most plausible approach is to integrate GS with doubled haploid breeding. In this case DH lines could be produced from $\mathrm{F}_{1}$ or $\mathrm{F}_{2}$ and the $\mathrm{DH}$ lines will be the BP which are genotyped but not phenotyped. The model predicts the GEBV of each DH (BP) lines and those with the highest GEBV are used as parents, and for yield trials across locations. With their phenotypic and genotypic data these DH lines serve also to retrain and re-calibrate the model. The integration of GS with DH is especially practical and effective for winter wheat breeding programs. For the spring bread wheat breeding program, it is possible to use the shuttle breeding and modified speed breeding program to advance the generation cycle and hence GS can be applied at preliminary yield trials or 1st year advanced yield trials stage and predict the performance of the lines across locations based on their corresponding GEBV.

3. Validation population (VP): This set of lines are both phenotyped and genotyped. Using these two data sets, the GEBV is determined for each of the VP lines. Correlation analysis is carried out between the GEBV and the actual phenotypic values of the VP lines to validate the efficiency of the model for genomic selection.

4. The expected genetic gain through time by the implementation of GS is defined as: $\chi G=i r \sigma_{A} / T$ where $i$ is the selection intensity, $r$ is the selection accuracy, $\sigma_{A}$ is the square root of the additive genetic variance, and $T$ is the length of time to complete one breeding cycle [90]. GS can be advantageous over PS for those traits such as grain quality, insect resistance and predict the performance of genotypes in other locations which are not easily accessible to undertake trials. The cost-benefit analysis of GS over phenotypic selection varies across breeding programs in different countries and the correlation of the GEBV with the field-based selections, and accordingly the decision to apply GS should be made by the respective programs. However, it should be noted that GS is not a replacement over PS. Currently, the cost of genotyping become cheaper, and it is attractive to include the GEBV as one along with agronomic data and breeders scores across locations to increase breeding efficiency and increase genetic gains.

\section{Exploring hybrid wheat}

In the past, hybrid wheat production was discouraged for its poor economic return, because of very limited heterotic advantage (10\%); lack of clear advantage in terms of agronomic, disease and quality traits; expensive seed production costs; and due to the argument that yield 
increment can be obtained using conventional/line varieties and consequently hybrids would have no biological advantage over inbred lines [91]. However, with time, it became apparent that hybrid wheats can provide higher and stable grain yield, better genetic gains, higher thousand grain weight, more tillers, higher biomass, deeper roots and better resistance to both biotic and abiotic stresses as compared to their parents [92]. Hybrid wheats can be produced using the chemical hybridizing agent, cytoplasmic male sterility and biotechnological systems.

Currently, hybrid wheat is predominantly produced in Europe using the chemical hybridization agent (CHA) CROISOR ${ }^{\circledR} 100$ (Hybridwheat 2013). The CHA system involves planting of the maternal line in strips alternating with the pollen donor (male) parent line. Only the maternal lines are sprayed at booting stage. Paternal lines with excellent anther extrusion are highly preferred for successful pollination and production of $F_{1}$ seeds. Genotype, environment, time of application and their interaction can influence the effectiveness of the CHA though in general CHA functions for a broad spectrum of genotypes with relatively very low toxicity in wheat [93]. The Cytoplasmic Male Sterility (CMS) method is based on the application of three parent systems involving the A, B, and R parents where A and B are identical except that B is not cytoplasmic sterile and hence it is used to maintain the A parent which is cytoplasmic sterile. $\mathrm{R}$ is the fertility restorer parent and the $F_{1}$ is produced by crossing A with $R$ parent $\left(A \times R=F_{1}\right)$. This system is used in USA, China, India and Australia. It is also anticipated that the application of biotechnological methods will help capture increased heterosis by direct selection of favorable alleles and the development of new genetically based systems to control male sterility such as the recessive split-gene transgene system which utilizes complimentary fragments of barnase to induce male-sterility in maternal plants while retaining pollen fertility and enables production of $F_{1}$ hybrid seeds [94]. Hybrid wheats are expected to adapt more on marginal areas and produce more stable and higher yields as compared to the conventional varieties. Currently, Bayer, Syngenta and Dow DuPont are working to develop their respective hybrid wheat varieties to Europe, USA, and Australian markets (https://www.futurefarming.com).

In all the systems, it is important to predict hybrid performance based on general combining ability (GCA) and specific combining ability (SCA). Recent studies have indicated that application of genomic selection has a great potential in predicting hybrid performance [95]. We hope that further identification of a stable and effective CHA, development of heterotic pools, and integration of molecular markers and genomic selection in the hybrid wheat breeding program will enable develop high yielding, stable and profitable wheat hybrids by improving the system efficiency, increasing heterosis, and reduction of the cost of hybrid seed production. 


\section{Key location phenotyping}

Key locations are representative locations to undertake germplasm phenotyping for one or more important stresses without significant fluctuations/variations through years under natural condition [66]. In this context, Merchouch and Sidi Alydi stations in Morocco for terminal drought stress; Sids station in Egypt for yield potential; Wadmedani station in Sudan for heat tolerance and Kulumsa station for rust and Septoria phenotyping have been established by ICARDA in partnership with the respective national programs. Furthermore, the Terbol station in Lebanon is an excellent station for undertaking winter $\times$ spring crosses and evaluation of germplasm for wide adaptation and cold tolerance. The regional rust lab facility at Izmir (Turkey) has licensed to import foreign rust isolates from anywhere around the world to undertake race analysis and screening of germplasm for seedling resistance. The wheat breeding at ICARDA tests, on average, 2000 spring bread wheat genotypes across the above locations and advances up to 700 the selected genotypes into advanced yield trials on annual basis. The selected genotypes do combine drought tolerance, yield potential, heat tolerance and of course resistance to rusts (Figure 4).

Marchouch + Sidi Al Aydi: Yellow rust, Septoria, drought tolerance, HF resistance

Sids: Yield potential

Izmir: Screening for rusts (Lab + field)

Kulumsa /Dz: Stem rust, yellow rust, septoria, fusarium

Wadmedani: Heat tolerance

Terbol: adaptation, yield potential, rusts, cold tolerance

Figure 4. Key locations of ICARDA's wheat breeding program.

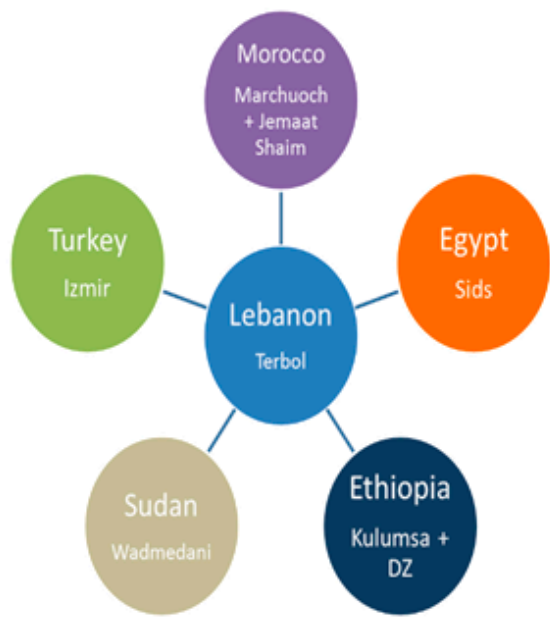

In the spring bread wheat breeding program at ICARDA, germplasm generations are segregated and shuttled between Terbol station in Lebanon, Sids station in Egypt, Kulumsa station in Ethiopia and Merchouch station in Morocco. This is followed by key location yield testing at Terbol (Lebanon), Marchouch and Sid al Aydi (Morocco), Sids (Egypt), Wadmedani (Sudan) and Izmir (Turkey) and Kulumsa (Ethiopia) (Figure 4). This enables to combine yield potential and wide adaptation with resistance to biotic and abiotic stresses.

As indicated in Figure 5, some of the genotypes such as 2, 26, 73, 100, 133, 155, 157 are high yielding at Wadmedani under excesses heat stress, Merchouch (terminal drought stress) and Sids (yield potential) indicating 
that these genotypes do combine yield potential with heat and drought tolerance [96]. This clearly demonstrates the power and significance of key locations in phenotyping and identification of varieties for specific and/or wide adaptation. Key locations are like diagnostic molecular markers and enables to develop and/identify varieties with different trait combinations.

Yield of wheat genotypes across key locations
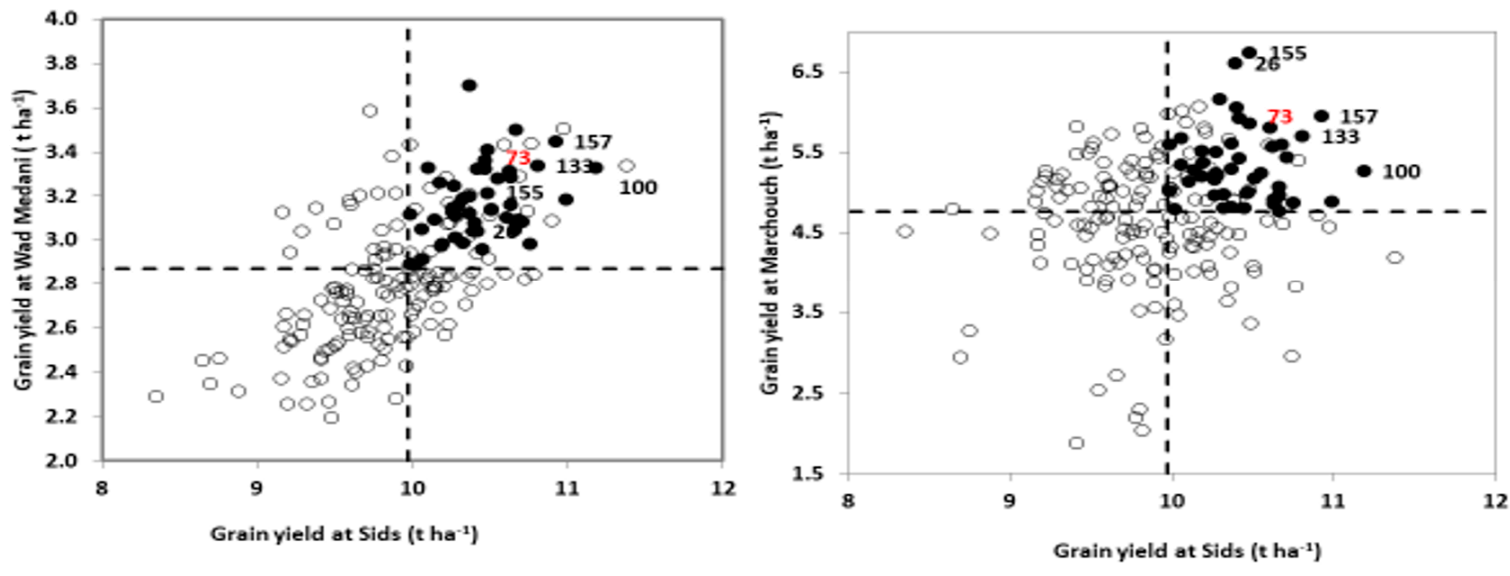

- Above average in SIDS, WM and Marchouch

Figure 5. Bi-plots of the performance of 200 elite spring bread wheat genotypes at three locations representing yield potential (Sids, Egypt), drought (Marchouch, Morocco) and heat stress (Wad Medani, Sudan) conditions.

\section{International Nurseries Distribution and Training}

International observation nurseries and yield trials are assembled targeting the different mega-environments such as irrigated environments, high rain fall areas, rainfed environments with terminal drought stress and environments with high temperature/heat stress during the growing season. These nurseries are distributed by CIMMYT and ICARDA based on request of the national programs and other partners. At ICARDA, we distribute annually more than 400 elite spring bread wheat genotypes composed in two observation nurseries (spring bread wheat observation nursery for dry areas and spring bread wheat observation nursery for heat tolerance) and three yield trials (Elite Spring Bread Wheat Yield Trials, Dry land Spring Bread Wheat Yield Trial and Spring Bread Wheat Yield Trial for heat stressed environments). Distribution of germplasm is limited mostly to fixed elite lines [97]. It is to be noted that germplasm distribution to NARS will not result to variety release and adoption unless there are trained breeders in the national and regional programs of each countries. To this end, the annual wheat improvement courses both at CIMMYT and ICARDA have been established. These trainings are multi-disciplinary involving breeding, genetics, biotechnology both in theory and practices. It has helped to promote the ideals of international germplasm development, collaboration and partnership in addition to successful variety release and adoption. 


\section{Variety Registration, Deployment and Impacts}

The distribution of elite wheat genotypes through the international nurseries to different countries have led to the direct release of more than 1500 wheat varieties from 1966 to 1990 . Currently, the CGIAR derived wheat varieties account more than $70 \%$ of the wheat production area in developing countries [97]. The adoption of improved varieties has increased from 93\% in 2002 to 97\% in 2014, and about 106 million hectares of the wheat area was covered by the CGIAR-related wheat varieties [98]. The most successful crosses to-date which led to the release of many outstanding cultivars include the VEERY cross (KVZ/BUHO//KAL/BB), Cham-6 (W3918A/JUP), Kauz (JUP/BJY//URES) and Attila cross (ND/VG9144 //KAL/BB/3/YACO/4/VEE\#5)[99]. The release and adoption of these varieties have contributed to an estimated yield increase of $2.53 \%$ year $^{-1}$ in the World from the pre-Green Revolution era until the end of the 20th century. The largest yield increases were observed in Asia and Africa (3.5 and 2.6\% year $^{-1}$ respectively), particularly in East and South Asia (4.4 and 3.2\% year $^{-1}$ respectively) and in South and North Africa (3.2 and $2.5 \%$ year $^{-1}$ respectively)[8]. Although improved agronomic techniques played a significant role most of the areas with the highest yield increases are also the largest adopter of the new CGIAR varieties, highlighting its importance in feeding the World during the 20th century.

During the first two decades of the 21st century, global wheat yields have increased at a lower rate than during the 20th century $(1.42 \%$ year $^{-1}$ [8]. This can be attributed partly to a decrease in wheat genetic gain rate observed in some developed countries as compared to previous periods and especially to the small room for improvement of agronomic techniques in areas where the adoption was already high during the 20th century. From 1994 to 2014, 4604 wheat varieties have been released globally by public (63\%) and private (37\%) breeding programs with the CGIAR-related varieties accounting $63 \%$ of the global releases. More than a quarter of such releases have been registered from 2010 to 2014 probably due to the introduction of Ug99 rust resistant varieties. In fact, East Africa-where Ug99 is originated and where the efforts for variety replacement have been larger and more successful-is the region where the yields have grown the largest in the world during this period $3.9 \%$ year-1), highlighting again the potential for wheat production improvement when the new varieties are successfully and efficiently transferred to the farmers. At regional level, CGIAR-related varieties account $97 \%$ in South Asia of which more than 50\% are direct releases. Similar levels have been reported in Central and West Asia and North Africa (CWANA) and Sub Saharan Africa (SSA) regions [98]. International breeding efforts focusing only on winter wheat started since 1986 through the establishment of IWWIP. To-date ca. 100 winter/facultative wheat varieties of IWWIP origin have been released in 11 countries of Central and West Asia including Afghanistan, Iran and Turkey [100]. These lines cover almost 2.5 Mha in the region and have broad genetic diversity. 
In general, the huge impact of the CGIAR WHEAT breeding programs have been testified not only by national governments, agricultural ministries, farmers and extention agents but also by some of the key donors such as the World Bank which reported that wheat is the first agricultural commodity in terms of percentage of area covered by improved varieties [101]. Annual benefit from the global wheat research ranges from 6.7 to 9.4 billion dollars. The benefit from CGIAR wheat research alone ranges from 2.3 to 3.1 billion dollar on annual basis [98]. The impact of international wheat research, however, is beyond financial estimates. Its contribution in terms of capacity development, food security, job creation, and conservation of natural resources is huge.

\section{BREEDING PROGRESS AND GENETIC GAINS}

The ultimate objective of any breeding program is to develop outstanding genotypes in terms of yield, adaptation, resistance to biotic and abiotic stresses, and end use qualities. These improvements should be measurable through time and space. Determining the breeding progress or the rate of genetic gain helps to evaluate breeding programs regularly in order to improve their efficiency. Different approaches and tools can be used to measure the rate of breeding progress or genetic gain. Vencovsky et al. [102] used data of common varieties from a trial which was carried out for certain period of times. In this approach, the year effect was estimated using the mean yield difference of the common varieties in two years while the rate of genetic gain was estimated by subtracting the yield of the variety in a particular year from the yield of the closest previous year without the year effect. Genetic gain estimation in this approach considers the effect of the genotype, environment and year. For example, genetic gains for two consecutive years can be calculated using the formula: $\operatorname{gd} 21=\operatorname{td} 21$ - ed21, where: $\operatorname{gd} 21$ is the genetic difference between year 2 and 1; td21 is the total difference between years 2 and 1 and ed21 is the environment difference between years 2 and 1 . To calculate the rate of genetic gain across the number of years, we have to divide the overall genotypic mean of the final year by the overall mean of the initial year [102]. Following this method, Cargnin et al. [103] annual grain yield increases of $1.84 \%$ since 1976. Regression analysis using the average yield of the top 5 genotypes divided by the trial mean and multiplied by 100 was used by Trethowan et al. [104] to estimate the rate of breeding progress. Success rate analysis by Tadesse et al. [99] was used to measure genetic gains over years or trials. In general, continuous improvements or progress have been reported at the international breading programs for grain yield and other traits [99,100,104,105].

In ICARDA's spring bread wheat breeding program, key location yield trials revealed that yield levels of the current top yielding elite genotypes range up to 6 thha ${ }^{-1}$ at Wadmedani station of Sudan under extreme heat stress, $7 \mathrm{t}^{\mathrm{h} \mathrm{h}^{-1}}$ at Merchouch station of Morocco under terminal moisture stress (260-300 mm) and $11 \mathrm{t} \cdot \mathrm{ha}^{-1}$ at Sids station in Egypt under optimum 
conditions. Genetic gain analysis from 1980 to 2017 showed 2.5, 1.3 and $2.3 \%$ year $^{-1}$ increment at Merchouch, Wadmedani and Sids stations, respectively [68]. Genetic improvements have been also reported for resistance to major diseases such as UG99 resistance, yellow rust resistance and Hesian fly resistance among others [106]. Progress in improving nutritional quality of wheat including the identification of Fe and $\mathrm{Zn}$ rich wheat varieties have been reported.

\section{FUTURE DIRECTIONS AND PROSPECTS}

The world population is increasing on annual basis at the average rate of $1.14 \%$ and it is projected to reach 9 billion in the year 2050 [107]. This is happening on the face of climate change where the global temperature is increasing, drought/moisture stress is expanding, high level of environmental degradation, and virulent pests and diseases of wheat are spreading across the different wheat growing regions. Furthermore, the increasing cost of inputs such as irrigation water, chemical fertilizer together and fuels will be constrained wheat production. We recommend the implementation of the following points to increase wheat production and ensure global food and nutritional security.

1. Design efficient system to undertake gene mining and utilization of genetic resources stored in gene banks. Available reports indicate that not more than $10 \%$ of such germplasm in the gene banks have been utilized by breeders to-date. It is therefore important to design and apply efficient strategies and tools such as Focused Identification of Germplasm Strategy (FIGS), cytogenetic and genomic tools and bioinformatics in order to efficiently mine genetic resources for breeders sought traits. Wild relatives will be highly relevant to add novel diversity including for adaptation to climate change adverse effects, calling for strengthening pre-breeding efforts.

2. The availability of modern cost-effective high throughput molecular tools and advanced statistical analysis would enable us to undertake genomic selection. Genomic selection enables to combine minor QTLs in shorter period of time and thereby increases the rate of genetic gains. From experiences to-date, many QTLs have been identified though with limited application/incorporation into the breeding programs. Hence while promoting genomic selection and other molecular tools, it is always important to keep the balance in investment in the field of phenotyping and molecular platforms.

3. Increasing the rate of wheat photosynthesis by changing/modifying the molecular pathways of wheat would help to increase wheat production by about $50 \%$. In this context, investing in physiological tools and approaches to change/improve the efficiency of key enzymes like Rubisco would be highly important.

4. There is a huge potential of genetically modified wheat to increase production through the development of wheat varieties with herbicide 
tolerance, drought, heat and disease resistance and improved nutritional qualities. However, to-date, there is little appetite by the general public and policy makers about GM wheats.

5. There is a huge potential in hybrid wheat to increase productivity for the fact that hybrids produce higher yields, deeper roots, higher biomass and better resistance to stresses. However, the lack of clear heterotic groups, and the high cost of seed production are the major constraints in the development of hybrid wheats. Application and utilization of new molecular tools will help to select directly the favourable alleles, and to develop genetically controlled male sterility systems for hybrid variety development and pyramiding in in relation to their parents.

6. Strengthening international net-works such as iwin, establishment of global phenotyping platforms for key biotic and abiotic stresses, strong partnership among international, national and regional public and private institutions will play important roles in developing and promoting wheat technologies to increase sustainable wheat production.

\section{CONFLICTS OF INTEREST}

The authors declare that they have no conflicts of interest.

\section{FUNDING}

This research was funded by ICARDA.

\section{ACKNOWLEDGMENTS}

Authors acknowledge the national programs in the CWANA and SSA regions for their partnership and collaboration.

\section{REFERENCES}

1. Percival J. The wheat plant. A monograph. New York (US): E. P. Dutton \& Company; 1921.

2. Nuttonson MY. Wheat-climatic relationships and the use of phenology in ascertaining the thermal and photothermal requirements of wheat. Silver Spring (US): American Institute of Crop Ecology; 1955.

3. Briggle LW, Curtis BC. Wheat Worldwide. In: Heyne EG, editor. Wheat and Wheat Improvement. Madison (US): American Society of Agronomy; 1987. p. 1-31.

4. Kihara H. Cytologische und genetische Studien bei wichtigen Getreidearten mit besonderer Rucksicht auf das Verhalten der Chromosomen und die Sterilität in den Bastarden. Kyoto (Japan): Memoirs of the College of Science, Kyoto Imperial University; 1924. German.

5. Braun HJ, Atlin G, Payne T. Multi-location testing as a tool to identify plant response to global climate change. In: Reynolds MP, editor. Climate change and crop production. Wallingford (UK): CABI Publishers; 2010. 
6. Braun HJ, Sãulescu NN. Breeding winter and facultative wheat. Rome (Italy): FAO; 2002. (FAO Plant Production and Protection Series).

7. Shiferaw B, Smale M, Braun HJ, Duveiller E, Reynolds M, Muricho G. Crops that feed the world 10. Past successes and future challenges to the role played by wheat in global food security. Food Secur. 2013;5:291-317.

8. FAO. FAOSTAT. Available from: http://faostat.fao.org. Accessed 2018 Nov 7.

9. Baum MW, Tadesse W, Nachit M, Abdalla O, Rajaram S, Singh R, et al. Global Crop Improvement Networks to Bridge Technology Gaps. In: Ogihara Y, Takumi S, Handa H, editors. Advances in Wheat Genetics: From Genome to Field: Proceedings of the 12th International Wheat Genetics Symposium; 2013 Sep 8-14; Yakohama, Japan. Tokyo (Japan): Springer Japan; 2015. p. 387-99.

10. Dixon J, Braun HJ, Crouch J. Transitioning wheat research to serve the future needs of the developing world. In: Dixon J, Braun HJ, Kosina P, editors. Wheat Facts and Futures. Mexico City (Mexico): CIMMYT; 2009. p. 1-19.

11. Rosegrant MW, Agcaoili M. Global Food Demand, Supply, and Price Prospects to 2010. Washington D.C. (US): International Food Policy Research Institute; 2010.

12. Feldman M, Levy AA. Allopolyploidy-A shaping force in the evolution of wheat genomes. Cytogenet Genome Res. 2005;109:250-8.

13. Gill BS, Friebe B. Cytogenetics, phylogeny and evolution of cultivated wheats. In: Bonjean AP, Angus WJ, editors. The world wheat book: A history of wheat breeding. Paris (France): Lavoiser Publishing; 2001.

14. Feldman M. Origin of cultivated wheat. In: Bonjean AP, Angus WJ, editors. The world wheat book: A history of wheat breeding. Paris (France): Lavoiser Publishing; 2001.

15. Dvorak J, di Terlizzi P, Zhang HB, Resta P. The evolution of polyploid wheats: identification of the A genome donor species. Genome. 1993;36:21-31.

16. Riley R, Chapman V. Genetic control of the cytologically diploid behaviour of hexaploid wheat. Nature. 1958;182:713-5.

17. Sears ER. Genetic control of chromosome pairing in wheat. Annu Rev Genet. 1976;10:31-51.

18. Qi L, Friebe B, Zhang P, Gill BS. Homoeologous recombination, chromosome engineering and crop improvement. Chromosome Res. 2007;15:3-19.

19. Feuillet C, Langridge P, Waugh R. Cereal breeding takes a walk on the wild side. Trends Genet. 2007;24:24-32.

20. Ogbonnaya FC, Abdalla O, Mujeeb-Kazi A, Kazi AG, Gosnian N, Lagudah ES. Synthetic hexaploids: harnessing species of the primary gene pool for wheat improvement. Plant Breed Rev. 2013;37:35-122.

21. Mujeeb-Kazi A, Hettel GP. Utilizing Wild Grass Biodiversity in Wheat Improvement: 15 Years of Wide Cross Research at CIMMYT. Mexico City (Mexico): CIMMYT; 1995. CIMMYT Research Report No. 2.

22. Chapman CGD. The role of genetic resources in wheat breeding. Plant Genet Res Newsl. 1986;65:2-5.

23. Maxted NA, Amri NP, Castaneda-Alvarez S, Dias ME, Dulloo H, Fielder BV, et al. Chapter 10: Joining up the dots: A systematic perspective of crop wild relatives conservation and Use. In: Maxted N, Ehsan M, Ford Lloyd BV, editors. 
Crop Genepool Use: capturing wild relative and landrace diversity for crop improvement. Wallingford (UK): CAB International; 2016.

24. Dempewolf H, Baute G, Anderson J, Kilian B, Smith C, Guarino L. Past and Future Use of Wild Relatives in Crop Breeding. Crop Sci. 2017;57:1070-82.

25. Mackay MC, Street K. Focused identification of germplasm strategy-FIGS. In: Black CK, Panozzo JF, Rebetzke GJ, editors. Cereals 2004: Proceedings of the 54th Australian Cereal Chemistry Conference and the 11th Wheat Breeders' Assembly. Melbourne (Australia): Royal Australian Chemical Institute; 2004. p. 138-41.

26. Bari A. A new approach to mining agricultural gene banks-to speed the pace of research innovation for food security. Aleppo (Syria): ICARDA, Research to Action No. 3; 2014. p. 16. ISBN: 92-9127-294-9.

27. El-Bouhssini M, Street K, Joubi A, Ibrahim Z, Rihawi F. Sources of wheat resistance to Sunn pest, Eurygaster integriceps Puton, in Syria. Genet Resour Crop Evol. 2009;56(8):1065-9.

28. Endresen DTF, Street K, Mackay M, Bari A, De Pauw E. Predictive association between biotic stress traits and ecogeographic data for wheat and barley landraces. Crop Sci. 2011;51:2036-55.

29. Endresen DTF, Street K, Mackay M, Bari A, Amri A, De Pauw E, et al. Sources of resistance to stem rust (Ug99) in bread wheat and durum wheat identified using focused identification of germplasm strategy. Crop Sci. 2012;52(2):76473. doi: 10.2135/cropsci2011.08.0427

30. Salvi S, Porfiri O, Ceccarelli S. Nazareno Strampelli, the 'Prophet' of the green revolution. J Agric Sci. 2013;151:1-5. doi: 10.1017/S0021859612000214

31. Dalrymple DG. Development and Spread of High-Yielding Wheat Varieties in Developing Countries. Bureau for Science and Technology. Washington D.C. (US): U.S. Agency for International Development; 1986.

32. Lupton FGH. History of wheat breeding. In: Lupton FGH, editor. Wheat Breeding: Its Scientific Basis. London (UK): Chapman and Hall; 1987.

33. Yang N, Smale M. Indicators of wheat genetic diversity and germplasm use in the people's republic of China. Mexico City (Mexico): CIMMYT; 1996. NRG Paper 96-04.

34. Borlaug NE. Feeding A World of 10 Billion People: Our 21st Century Challenge. In: Scanes CG, Miranowski JA, editors. Perspectives in World Food and Agriculture 2004. Ames (US): Iowa State Press; 2008. p. 32-56.

35. Kihara H. Origin and history of 'Daruma', a parental variety of Norin 10. In: Sakamoto S, editor. Proceedings of the 13th International Wheat Genetics Symposium. Kyoto (Japan): Plant Germplasm Institute, University of Kyoto; 1983.

36. Borlaug NE. Challenges for global food and fiber production. J Royal Swed Acad Agric For. 1988;21:15-55.

37. Reynolds MP, Dreccer F, Trethowan R. Drought adaptive traits derived from wheat wild relatives and landraces. J Exp Bot. 2007;58:177-86.

38. Trethowan RM, van Ginkel M. Synthetic wheat-An Emerging Genetic Resource. In: Carver BF, editor. Wheat: science and trade. Ames (US): WileyBlackwell; 2009. 
39. Placido DF, Campbell MT, Folsom JJ, Cui X, Kruger GR, Baenziger PS, et al. Introgression of novel traits from a wild wheat relative improves drought adaptation in wheat. Plant Physiol. 2013;161:1806-19.

40. Dreccer MF, Ogbonnaya FC, Borgognone G, Wilson J. Boron tolerance is present in primary synthetic wheats. Proceedings of the 10th International Wheat Genetics Symposium; 2003 Sep 1-6; Paestum, Italy.

41. Ogbonnaya FC, Ye G, Trethowan R, Dreccer F, Lush D, Shepperd J, et al. Yield of synthetic backcross-derived lines in rainfed environments of Australia. Euphytica. 2007;157:321-36.

42. Lage J, Trethowan RM, Hernandez E. Identification of site similarities in western and central Asia using CIMMYT international wheat yield data. Plant Breed. 2008;127:350-4.

43. Emebiri LC, Ogbonnaya FC. Exploring the synthetic hexaploid wheat for novel sources of tolerance to excess boron. Mol Breed. 2015;35:1-10.

44. Roelfs AP. Resistance to leaf and stem rust in wheat. In: Simmonds NW, Rajaram S, editors. Breeding strategies for resistance to the rusts of wheat. Mexico City (Mexico): CIMMYT; 1988.

45. Hajjar R, Hodgkin T. The use of wild relatives in crop improvement: a survey of developments over the last 20 years. Euphytica. 2007;156:1-13.

46. McIntosh RA, Wellings CR, Park RF. Wheat rusts: an atlas of resistance genes. East Melbourne (Australia): CSIRO Publications; 1995.

47. Stakman EC, Harrar JG. Principles of Plant Pathology. New York (US): Ronald Press; 1957.

48. Singh RP, Huerta-Espino J, Sharma R, Joshi AK, Trethowan R. High yielding spring bread wheat germplasm for global irrigated and rainfed production systems. Euphytica. 2007;157:351-63.

49. Villareal RL, Singh RP, Mujeeb-Kazi A. Expression of resistance to Puccinia recondita f.sp. tritici in synthetic hexaploid wheats. Vortr Pflanzenzuchtg. 1992;24:253-5.

50. Tadesse W, Schmolke M, Mohler V, Wenzel G, Hsam SLK, Zeller FJ. Molecular mapping of resistance genes to tan spot (Pyrenophora tritici-repentis race 1) in synthetic wheat lines. Theor Appl Genet. 2007;114:855-62.

51. El-Bouhssini M, Ogbonnaya FC, Chen M, Lhaloui S, Rihawi F, Dabbous A. Sources of resistance in primary synthetic hexaploid wheat (Triticum aestivum L.) to insect pests: Hessian fly, Russian wheat aphid and Sunn pest in the fertile crescent. Genet Res Crop Evol. 2013;60:621-7.

52. US Wheat Associates, 2019. Weekly price report. Available from: https://www.uswheat.org/market-and-crop-information/price-reports. Accessed 2019 May 1.

53. Canadian Wheat Board, 2011. Available from: http://www1.agric.gov.ab.ca/\$department/deptdocs.nsf/all/sis14235. Accessed 2019 May 1.

54. Sanchez-Garcia M, Álvaro F, Peremarti A, Martín-Sánchez JA, Royo C. Changes in bread-making quality attributes of bread wheat varieties cultivated in Spain during the 20th century. Eur J Agron. 2015;63:79-88. doi: 10.1016/j.eja.2014.11.006 
55. Goel S, Singh B, Grewal S, Jaat RS, Singh NK. Variability in Fe and Zn content among Indian wheat landraces for improved nutritional quality. Indian J Genet Plant Breed. 2018;78(4):426-32.

56. Sciacca F, Allegra M, Licciardello S, Roccuzzo G, Torrisi B, Virzì N, et al. Potential use of sicilian landraces in biofortification of modern durum wheat varieties: Evaluation of caryopsis micronutrient concentrations. Cereal Res Commun. 2018;46(1):124-34. doi: 10.1556/0806.45.2017.056

57. Rasheed A, Jin H, Xiao Y, Zhang Y, Hao Y, Zhang Y, et al. Allelic effects and variations for key bread-making quality genes in bread wheat using highthroughput molecular markers. J Cereal Sci. 2019;85:305-9.

58. Lage L, Skovmand B, Peña RJ, Andersen SB. Grain quality of emmer wheat derived synthetic hexaploid wheats. Genet Resour Crop Evol. 2006;53:955-62.

59. Ortiz-Monasterio JI, Palacios-Rojas N, Meng E, Pixley K, Trethowan R, Peña RJ. Enhancing the mineral and vitamin content of wheat and maize through plant breeding. J Cereal Sci. 2007;46:293-307.

60. Payne T. The international wheat improvement network (IWIN) at CIMMYT. Available from: www.cimmyt.org. Accessed 2019 May 1.

61. Reynolds MP, Borlaug NE. Impacts of breeding on international collaborative wheat improvement. J Agric Sci. 2006;144:3. doi: 10.1017/S0021859606005867

62. Rajaram S, van Ginkel M, Fischer RA. CIMMYT's wheat breeding megaenvironments (ME). Proceedings of the 8th International Wheat Genetic Symposium; 1993 Jul 19-24; Beijing, China.

63. Ferrara O, Mulitze D, Yau SK. Bread wheat breeding for tolerance to thermal stresses occurring in West Asia and North Africa. Proceedings of the International Symposium on Improvement and management of winter cereals under temperature, drought and salinity stresses; 1987 Oct 26-29; Cordoba, Spain.

64. van Ginkel M, Trethowan RM, Ammar K, Wang J, Lillemo M. Guide to Bread Wheat Breeding at CIMMYT. Mexico City (Mexico): CIMMYT; 2002. Wheat Special Report No. 5.

65. Singh RP, Rajaram S, Miranda A, Huerta-Espino J, Autrique E. Comparison of two crossing and four selection schemes for yield, yield traits, and slow rusting resistance to leaf rust in wheat. Euphytica. 1998;100:35-43.

66. Tadesse W, Nachit M, Abdalla O, Rajaram S. Wheat Breeding at ICARDA: Achievements and Prospects in the CWANA Region. In: Bonjean A, Angus B, van Ginkel M, editors. The World Wheat Book: A History of Wheat Breeding. Volume 3. Paris (France): Lavoiser Publishing; 2016. ISBN: 9978-2-7430-2091-0.

67. Singh RP, Huerta-Espino J. The use of 'single-backcross, selected-bulk' breeding approach for transferring minor genes based rust resistance into adapted cultivars. In: Black CK, Panozzo JF, Rebetzke GJ, editors. Cereals 2004: Proceedings of the 54th Australian Cereal Chemistry Conference and the 11th Wheat Breeders' Assembly. Melbourne (Australia): Royal Australian Chemical Institute; 2004. p. 48-52.

68. Tadesse W, Tawkaz S, El-Hanafi S, Skaf P, Sherif A, Tahir I, et al. Genetic gains for yield, drought/heat tolerance and resistance to diseases in ICARDA's 
spring bread wheat germplasm targeted for the CWANA and SSA regions. Proceedings of the BGRI workshop; 2018 Apr 14-7; Marrakech, Morocco.

69. Borlaug NE. Wheat breeding and its impact on world food supply. In: Finlay KW, Shephard KW, editors. Proceedings of the 3rd International Wheat Genetics Symposium. Canberra (Australia): Australian Academy of Sciences; 1968. p. 1-36.

70. Hoogendoorn J, Pfeiffer WH, Rajaram S, Gale MD. Adaptive aspects of dwarfing genes in CIMMYT germplasm. In: Miller TE, Koebner RMD, editors. Proceedings of the 7th International Wheat Genetics Symposium. Cambridge (UK): 1988. p. 1093-100.

71. Tadesse W, Sanchez-Garcia M, Tawkaz S, Baum M. Doubled haploid production in Wheat. In: Ordon F, Friedt W, editors. Advances in crop breeding techniques for cereal crops. Cambridge (UK): Burleigh Dodds Science Publishing; 2019. (Burleigh Dodds Series in Agricultural Science).

72. Hu D, Tang Y, Yuan Z, Wang J. The induction of pollen sporophytes of winter wheat and the development of the new variety Jinghua. Sci Agric Sin. 1983;1:29-35.

73. De Buyser J, Lonnet P, Hertzoc R, Hespel A. "Florin”: doubled haploid wheat variety developed by the anther culture method. Plant Breed. 1987;98:53-6.

74. De Pauw RM, Knox RE, Humphreys DG, Thomas JB, Fox SL, Brown PD, et al. New breeding tools impact Canadian commercial farmer fields. Czech J Genet Plant Breed. 2011;47:28-34.

75. Săulescu NN, Ittu G, Giura A, Mustăţea P, Ittu M. Results of using Zea method for doubled haploid production in wheat breeding at Nardi FunduleaRomania. Rom Agric Res. 2012;29:3-8.

76. Chauhan H, Khurana P. Use of doubled haploid technology for development of stable drought tolerant bread wheat (Triticum aestivum L.) transgenics. Plant Biotechnol J. 2011;9:408-17.

77. Wu X, Chang X, Jing R. Genetic insight into yield-associated traits of wheat grown in multiple rain-fed environments. PLoS One. 2012;7(2):e31249. doi: 10.1371/journal.pone.0031249

78. Gu XY, Zhang L, Glover KD, Chu C, Xu SS, Faris JD, et al. Genetic variation of seed dormancy in synthetic hexaploid wheat-derived populations. Crop Sci. 2010;50:1318-24. doi: 10.2135/cropsci2009.11.0645

79. Reynolds M, Manes Y, Izanloo A, Langridge P. Phenotyping approaches for physiological breeding and gene discovery in wheat. Ann Appl Biol. 2009;155:309-20. doi: 10.1111/j.1744-7348.2009.00351.x

80. Srinivasachary, Gosman N, Steed A, Simmonds J, Leverington-Waite M, Wang $\mathrm{Y}$, et al. Susceptibility to Fusarium head blight is associated with the Rht-D1b semi-dwarfing allele in wheat. Theor Appl Genet. 2008;116:1145-53. doi: 10.1007/s00122-008-0742-2

81. Lu Y, Bowden RL, Zhang G, Xu X, Fritz AK, Bai G. Quantitative Trait Loci for Slow-Rusting Resistance to Leaf Rust in Doubled-Haploid Wheat Population CI13227 × Lakin. Phytopathology. 2017;107:1372-80. doi: 10.1094/PHYTO-0916-0347-R

Crop Breed Genet Genom. 2019;1:e190005. https://doi.org/10.20900/cbgg20190005 
82. Abd El-Maksoud MM, Karsai I, Bedö Z. Agronomic traits of wheat lines developed by the doubled haploid, single seed descent and pedigree methods after three cycles of selection. Acta Agron Hung. 1993;42:377-82.

83. Inagaki MN, Varughese G, Rajaram S, van Ginkel M, Mujeeb-Kazi A. Comparison of bread wheat lines selected by doubled haploid, single-seed descent and pedigree selection methods. Theor Appl Genet. 1998;97:550-6.

84. Li H, Singh RP, Braun HJ, Pfeiffer WH, Wang J. Doubled haploids versus conventional breeding in CIMMYT wheat breeding programs. Crop Sci. 2013;53(1);74-83.

85. Bakhtiar F, Afshari F, Najafian G, Mohammadi M. Backcross-breeding and doubled-haploid facilitated introgression of stripe rust resistance in bread wheat. Arch Phytopathol Plant Prot. 2014;47:1675-85. doi: 10.1080/03235408.2013.854612

86. Grafius JE. Short cuts in plant breeding. Crop Sci. 1965;5:337.

87. William HM, Trethowan RM, Crosby-Galvan EM. Wheat breeding assisted by markers: CIMMYT’s experience. Euphytica. 2007;157(3):307-19.

88. Sanchez-Garcia M, Bentley AR. Marker-assisted trait introgression for wheat breeding \& research. In: Ordon F, Friedt W, editors. Advances in crop breeding techniques for cereal crops. Cambridge (UK): Burleigh Dodds Science Publishing; 2019. (Burleigh Dodds Series in Agricultural Science).

89. Kuchel H, Ye G, Fox R, Jefferies S. Genetic and economic analysis of a targeted marker-assisted wheat breeding strategy. Mol Breed. 2005;16:67-78. doi: 10.1007/s11032-005-4785-7

90. Falconer DS, Mackay TFC. Introduction to quantitative genetics. 4th ed. New York (US): Longman; 1996.

91. Pickett AA, Galwey NW. A further evaluation of hybrid wheat. Plant Variet Seeds. 1997;10:15-32.

92. Longin CFH, Mühleisen J, Maurer HP, Zhang H, Gowda M, Reif JC. Hybrid breeding in autogamous cereals. Theor Appl Genet. 2012;125:1087-96.

93. Kempe K, Gils M. Pollination control technologies for hybrid breeding. Plant Breed. 2011;27:417-37.

94. Kempe K, Rubtsova M, Gils M. Intein-mediated protein assembly in transgenic wheat: production of active barnase and acetolactate synthase from split genes. Plant Biotechnol J. 2009;7:283-97.

95. Zhao Y, Zeng J, Fernando R, Reif JC. Genomic prediction of hybrid wheat performance. Crop Sci. 2013;53:802-10.

96. Tadesse W, Suleiman S, Tahir I, Sanchez-Garcia M, Jighly A, Hagras A, Thabet S, et al. Heat-Tolerant QTLs Associated with Grain Yield and Its Components in Spring Bread Wheat under Heat-Stressed Environments of Sudan and Egypt. Crop Sci. 2018;59:199-211. doi: 10.2135/cropsci2018.06.0389

97. Byerlee D, Moya P. Impacts of international wheat breeding research in the developing world, 1966-1990. Mexico City (Mexico): CIMMYT; 1993. p. 135.

98. Lantican MA, Braun HJ, Payne TS, Singh R, Sonder K, Baum M. Impacts of international wheat improvement research in the world, 1994-2014. Mexico City (Mexico): CIMMYT; 2015. 
99. Tadesse W, Manes Y, Singh R, Payne T, Crossa J, Braun HJ. Adaptation and performance of CIMMYT spring wheat genotypes targeted to high rainfall areas of the world. Crop Sci. 2010;50:240-8.

100. Tadesse W, Morgounov AI, Braun HJ, Akin B, Keser M, Yuksel K, et al. Breeding Progress for Yield and Adaptation of Winter Wheat Targeted to Irrigated Environments at the International Winter Wheat Improvement Program (IWWIP). Euphytica. 2013;194:177-85. doi: 10.1007/s10681-013-0903-5

101. World Bank. World Development Report, 2008. Washington D.C. (US): The World Bank; 2008.

102. Vencovsky R, Moraes AR, Garcia JC, Teixeira NM. Progresso genético em vinte anos de melhoramento do milho no Brasil. In: Embrapa Milho e Sorgo-Artigo em anais de congresso (ALICE). Sete Lagoas (Brazil): EMBRAPA-CNPMS; 1988. p. 300-7. Portuguese.

103. Cargnin A, de Souza MA, Fronza V. Progress in breeding of irrigated wheat for the Cerrado Progress in breeding of irrigated wheat for the Cerrado region of Brazil. Crop Breed Appl Biotechnol. 2008;8:39-46.

104. Trethowan RM, van Ginkel M, Rajaram S. Progress in breeding wheat for yield and adaptation in global drought affected environments. Crop Sci. 2002;42:1441-6.

105. Sharma RC, Crossa J, Velu G, Huerta-Espino J, Vargas M, Payne TS, et al. Genetic gains for grain yield in CIMMYT spring bread wheat across international environments. Crop Sci. 2012;52:1522-33.

106. Solh M, Nazari K, Tadesse W, Wellings CR. The Growing Threat of Stripe Rust World Wide. Proceedings of the Borlaug Global Rust Initiative (BGRI) conference; 2012 Sep 1-4; Beijing, China.

107. Alexandratos N. Critical Evaluation of Selected Projections. Proceedings of the Expert meeting on "How to feed the world in 2050”. 2009 Jun 24-6; Roma, Italy.

How to cite this article:

Tadesse W, Sanchez-Garcia M, Assefa SG, Amri A, Bishaw Z, Ogbonnaya FC, Baum M. Genetic Gains in Wheat Breeding and Its Role in Feeding the World. Crop Breed Genet Genom. 2019;1:e190005. https://doi.org/10.20900/cbgg20190005 